\title{
Length of Stay Abroad and Cultural Influences on Food Choice: A Study of Nigerians in South Africa
}

\author{
Abosede ljabadeniyi \\ Foundation and Academic Support Programmes Unit, \\ Midrand Graduate Institute, Midrand, South Africa, 1685 \\ abosedei@mgi.ac.za

\section{Oluwatosin A ljabadeniyi} \\ Department of Biotechnology \& Food Technology, Durban University of Technology, \\ Durban, South Africa, 4001 \\ oluwatosini@dut.ac.za
}

Doi:10.5901/mjss.2014.v5n4p632

\begin{abstract}
The aim of this paper is to investigate the relationship between length of stay abroad and cultural influences on food choice. Cultural influences on food choice were measured based on preference for cultural food, level of satisfaction derived from cultural food, food-adventurism, willingness to pay for and consumption patterns of cultural food. A self-administrated questionnaire was used to collect data. The study covered a sample size of 42 males and 23 females between the ages of 18 - 45 and above. Participants were judgmentally recruited in Pretoria and Durban, South Africa. The Statistical Package for Social Sciences (SPSS) software was used to analyse data. The results showed that respondents identified with their cultural food, regardless of the number of years stayed in South Africa. The findings of the study justify the profitability of the Nigerian food market, which consequently suggest potential for job opportunities and economic growth in South Africa.
\end{abstract}

Keyword: Cultural influences, food choice, cultural food and Nigerians in South Africa.

\section{Introduction}

The post-apartheid years in South Africa have witnessed the influx of foreign nationals from all over Africa. This has positively influenced aggregate demand, which in turn stimulated production activities to offset demand. The food industry is no exception, considering the intrinsic importance of food to human existence.

Food is one of the most important human needs (Neeliah \& Goburdhun, 2007). Alongside with water and oxygen, they provide the human body with organic and inorganic substances imperative to sustain its biological existence. According to Jones (1992), food supplies the energy the body requires to engage in physical and work related activities. In addition, food is said to be responsible for the repairs of worn out tissues in the body, in that it balances the wear and tear of everyday life and provides necessary substances needed for the growth of the body.

The importance of food; the first physiological need in Maslow's hierarchy of needs cannot be overemphasised. However, perceptions and correlation of sensory impressions of different types of food vary across countries or cultures, which determines individuals' preference for and attitudes toward food.

Factors such as age, health, socio-economic status, environment, religion, attitude, personal freedom, instinct, customs, appetite and choices have all been reported to influence the sensory impressions of food (Shepherd \& Raats, 2012). Culture, which is intertwined with some of the factors itemised above, could have moderating effects on individuals' sensory impressions of food. Particular attention should be paid to the influence of culture on sensory impressions as it plays a huge role in consumers' preference for food, willingness to pay and consumption patterns.

Culture has been described as the mutual working of the mind. Culture differentiates members of a group of people from others. As such, individuals learn to be cultured. Culture is different from human nature and an individual's personality. However, both the human nature and personality are modified by culture. Culture therefore comprises implicit rules that govern the social interactions amongst a group of people (Hofstede, Hofstede \& Minkov, 2010). A substantial proportion of the implicit rules that govern culture are manifested in individuals' sensory impressions of food. 
Therefore, ethnic group subcultures and individuals' preference for food are intertwined.

While culture adhesively binds a group of people together, the human community, individuals and social organisations are all expressed by culture. Cultural values, beliefs, customs, norms, attitudes and roles reside amongst a group of people who speak a uniform language, who chronological coexist, and live in a particular geographic region (de Mooij, 2011). It is important to note that cultural values, beliefs, customs and norms are expressed in artifacts such as food.

However, this present era has witnessed the overlap and hybridisation of cultural values and norms. One of the major factors responsible for the change in cultural values is globalisation (de Mooij, 2011). The overarching question is: Is the influence of the globalised culture evident on consumers' preference for cultural food?

\section{Conceptual Background}

Nigerians are known to migrate all around the world, especially to specific regions in sub-Suharan Africa. An estimate of Nigerians in Diaspora shows that about 20 million of the Nigerian population reside outside the shores of the country. While 5 million live in the UK, 4-6 million have their base in the US. Ghana and South Africa are said to be home to 2 million Nigerians, while a little above a million live in Ivory Coast (Drusilla, 2006).

The people of Nigeria are popularly known to have a relentless spirit and business-minded disposition, a phenomenon which keeps Nigerians afloat in diverse economic circumstances (Adichie, 2009). The aforementioned have a linear relationship with the prolific trade engagements Nigeria maintains with other countries.

The country's food basket is abundantly endowed. Most Nigerian cuisines are based on food eaten with stew and food made from crops such as yam, cassava, potatoes, maize, rice, beans, as well melon seeds and "ogbono" seeds. Many Nigerian meals are processed into powdered forms, which are often pounded or stirred into a thick, sticky dough or paste. These meals are often served with stews/soups made with chicken, beef, goat meat or fish. The stews are prepared with a blend of tomatoes, paprika, chilies and onions. The most common traditional soups prepared abroad are made from melon seeds and "ogbono" seeds. These seeds serve as thickeners in most Nigerian soups, which could be garnished with diverse vegetables like spinach, etc. Locally prepared Nigerian meals are by convention eaten with bare hands (Advameg, 2012).

Given the rich composition of the Nigerian diet, an enquiry into the influence of length of stay abroad on the loyalty tendency of Nigerians residing in South Africa to their cultural food is indisputably timeous, considering the Nigerian population in South Africa. This enquiry is especially crucial when considering the similarities between the cultural foods of most West African countries, whose citizens are vastly represented in South Africa.

\section{Research Design}

Research methodology remains the backbone of any research effort. Research design has been defined as the cautiously planned organisation of conditions for analysis and data collection in a way that aims to combine relevance to the research goals in a cost effective manner (Cooper \& Schindler, 2006). Sekaran and Bougie (2013) state that the approach employed in a research design depends to a large extent on the nature and requirements of the problem. An outline of the research design is discussed below:

\subsection{Problem Definition}

One of the major challenges foreign nationals encounter abroad is adapting their tastes buds in the context of the native food of the host country. This inspired an enquiry into Nigerians' loyalty tendency to their cultural food in South Africa based on preference, satisfaction, food-adventurism, willingness to pay and consumption patterns. While there has been an increase in socio-cultural engagements between South Africans and Nigerians since the beginning of the postapartheid era, an investigation into the loyalty tendency of Nigerians to their cultural food is critical, considering the Nigerian population in South Africa and the possible business opportunities that could emanate from the study. Moreover, this study is especially timeous in the wake of the global economic crisis, which urgently requires the identification of strategic business opportunities needed to stimulate economic growth and consequently create job opportunities. 


\subsection{Research Approach}

This study used quantitative approach to analyse data. Quantitative research methods are useful for analysing consumer behaviour. Quantitative research uses structured questionnaires to collect data, the use of structured questionnaires has been advocated in that it makes it easy for data to be analysed into user friendly forms. More so, quantitative research provides an avenue to generalise the attribute of a research sample to a larger population (Leedy \& Ormrod, 2005).

\subsection{Target Population}

According to Hofstede \& Hofstede (2005), culture is shared among groups of people residing in the same geographical location. Ember \& Ember (2001) stated the importance of drawing samples from the same geographical location in cultural research. The target population for this study is Nigerian consumers residing in South Africa. The rationale for selecting Nigerians in South Africa is based on the population of Nigerians in South Africa, the substantial trading activities between both countries and the economic stance of Nigeria in sub-Saharan Africa. The sample for this study was confined to two of the most popular cities in South Africa; Pretoria and Durban in the Gauteng and KwaZulu-Natal provinces respectively. The majority of the sample was taken from one of the most popular Nigerian settlements in Pretoria; Sunnyside. The Durban sample was taken from Berea.

\subsection{Sample Size \& Sampling Technique}

Sekaran and Bougie (2013) recommend that a sample size ranging between 30 and 500 is acceptable in quantitative research, depending on research questions. As such, the sample size for this study was 70 . A non-probability judgmental sampling technique was undertaken for this study.

\subsection{Questionnaire Design}

A structured questionnaire consisting two sections was used to collect data for this study. The first section of the questionnaire was devoted to collecting data on the demographic features of respondents while the second section measured respondents' loyalty tendency to their local food based on preference, satisfaction, food adventurism, willingness to pay and consumption pattern. The items contained in the section were measured on a five point Likert scale ranging from 'strongly disagree' to 'strongly agree'. The questionnaire was self-administered. A total number of 65 questionnaires were deemed useful for the study. Respondents were approached randomly in a culturally friendly manner without coercion, from different age groups, excluding minors. The questions for this study were phrased in line with the objectives of the study to ensure face validity. Reliability was ensured by pre-testing the questionnaire to ensure respondents fully understand the content of the questionnaire.

\subsection{Hypotheses}

The following hypotheses were formulated for this study:

- $\mathrm{H}_{0}$ : There is no significant association between the length of stay of Nigerians in South Africa and preference for cultural food

- $\quad \mathrm{H}_{1}$ : There is a significant association between the length of stay of Nigerians in South Africa and preference for cultural food

\subsection{Data Analysis}

Preliminary data analysis took the form of check listing, editing, coding and transcribing. The statistical analyses for this study were descriptive and inferential analysis. Descriptive analysis mainly used charts while inferential analysis took the form of a Chi-square test and correlation analysis. Data were analysed using SPSS and the respective associative analyses were conducted. 


\subsection{Results and Discussion}

The findings obtained for this study are presented in this section. As illustrated in Figure 3.1, it is evident that the majority of the respondents are loyal to their cultural food based on the items measured. The findings of the Chi-square test conducted to determine the association between length of stay in South Africa and preference cultural food are discussed further.

The analysis obtained from SPSS, at a significance level of 0.05 using the Chi-square test of independence showed no significant association between Nigerians' length of stay in South Africa and their preference for cultural food. As illustrated in Table 3.2, 31\% of the respondents have stayed in South Africa between 1 and 4 years, $46 \%$ have stayed in South Africa between 5 and 8 years while 23\% of the respondents have stayed in South Africa for more than 8 years. Amongst the $31 \%$ of the respondents who have been in South Africa for four years, only 3\% opine that local meals are not the best option. More so, while the majority of the respondents (46\%) have stayed in South Africa between 5 and 8 years, $39 \%$ of the $46 \%$ agree that local meals are the best option. Finally, only $3 \%$ of the $23 \%$ who have been in South for over 8 years are of the view that local meals are not the best option.

The Chi-square test reveals no significant association between respondents' length of stay in South Africa and preference for cultural food. The Decision Rule; to reject or accept $\mathrm{H}_{0}$ relied on the value of the Asymp Sig. (2-sided) test. As such, it was speculated that if "Asymp. Sig. (2-sided)" is less than the significance level $(0.05)$, Ho would be rejected and it would be concluded that there is a significant association between Nigerians' length of stay in South Africa and preference for cultural food. Otherwise, Ho would be accepted if "Asymp. Sig. (2-sided)" is greater than the significance level $(0.05)$ and it would be concluded that there is no significant association between Nigerians' length of stay in South Africa and preference for cultural food.

The findings conducted show that Asyp. Sig. yielded a value of .318 which is greater than 0.05 , hence, it can be concluded that there is no significant association between Nigerians' length of stay in South Africa and preference for cultural food. As such the null hypothesis is accepted while the alternative hypothesis is rejected.

Respondents' gender in relation to age group and marital status are presented in Table 3.3. It can be deduced from the table that the majority of the respondents $(64.6 \%)$ were male while $35.4 \%$ were female. The cross-tabulation reveals that $33.3 \%$ of the respondents were single, out of which $14 \%$ fall within the $18-24$ years, $57.1 \%$ within $25-31$ years and $28.6 \%$ within $32-38 y e a r s$. The results show that $66.7 \%$ of the male respondents and $56.5 \%$ of female respondents were married. While $50 \%$ of the married male respondents were within the age group of $25-31,32 \%$ fall within $39-45$ and $18 \%$ were over $45 y e a r s$. The findings of the study show that $46 \%$ of married female respondents fall within $25-31$ years, $38 \%$ within $32-38$, $8 \%$ within $39-45$ and $8 \%$ above 45 years.

Consequently, the fact that most respondents were married suggests that respondents were affiliated to some family in South Africa. According to Schiffman et al. (2010), two or more people living together and related biologically, maritally or by adoption can be regarded as a family. In addition, individuals are influenced by the family (Du Plessis \& Rouseau, 2007). Moreover, cultural cues like collectivism, loyalty to family, respect for elders and obligations to social and economic needs of relatives are to be found in Africa (Beugre \& Offodile, 2001). As such, there could be a similarity between the loyalty tendencies to cultural food amongst respondents' family members.

Table 3.1: Chi-Square Tests illustrating association between length of stay and preference for cultural food

\begin{tabular}{|l|c|c|c|}
\hline & Value & $\mathrm{df}$ & Asymp. Sig. (2-sided) \\
\hline Pearson Chi-Square & $2.292^{\mathrm{a}}$ & 2 & .318 \\
Likelihood Ratio & 2.053 & 2 & .358 \\
Linear-by-Linear Association & 1.358 & 1 & .244 \\
N of Valid Cases & 65 & & \\
\hline
\end{tabular}


Table 3.2: Length of Stay in South Africa (measured in years) * Preference for local meals

\section{Cross-tabulation}

\begin{tabular}{|c|c|c|c|c|c|}
\hline \multirow[t]{2}{*}{ Count } & & \multicolumn{3}{|c|}{ Stay in SA (in years) } & \multirow{2}{*}{ Total } \\
\hline & & Below 4 years & Between 5 and 8 years & Above 8 years & \\
\hline \multirow[t]{2}{*}{ When it comes to food, local meals are the best option } & Disagree & 2 & 3 & 2 & 7 \\
\hline & Agree & 18 & 27 & 13 & 58 \\
\hline Total & & 20 & 30 & 15 & 65 \\
\hline
\end{tabular}

Table 3.3: Age group * Gender * Marital status Cross-tabulation

\begin{tabular}{|c|c|c|c|c|c|c|c|c|c|}
\hline & \multicolumn{8}{|c|}{ Gender } & Total \\
\hline \multirow[t]{2}{*}{ Age Group } & \multicolumn{3}{|c|}{ Male } & \multirow{2}{*}{$\begin{array}{c}\text { Gender } \\
\text { Subtotal } \\
\end{array}$} & \multicolumn{3}{|c|}{ Female } & \multirow{2}{*}{$\begin{array}{c}\text { Gender } \\
\text { Subtotal }\end{array}$} & \\
\hline & Single & Married & Divorced & & Single & Married & Divorced & & \\
\hline $\begin{array}{l}\text { 18-24 Count } \\
\% \text { within age group } \\
\% \text { within gender } \\
\% \text { of Total population }\end{array}$ & 2 & - & - & $\begin{array}{c}2 \\
100 \% \\
4.8 \% \\
3.1 \% \\
\end{array}$ & - & $\begin{array}{l}- \\
\end{array}$ & $\begin{array}{l}- \\
-\end{array}$ & $\begin{array}{l}- \\
- \\
- \\
-\end{array}$ & \begin{tabular}{|c|}
2 \\
$100 \%$ \\
$4.8 \%$ \\
$3.1 \%$ \\
\end{tabular} \\
\hline $\begin{array}{l}25-31 \text { Count } \\
\% \text { within age group } \\
\% \text { within gender } \\
\% \text { of Total population }\end{array}$ & 8 & - & - & $\begin{array}{c}8 \\
38.1 \% \\
19.4 \% \\
12.3 \% \\
\end{array}$ & $\begin{array}{c}7 \\
33.3 \%\end{array}$ & $\begin{array}{c}6 \\
286 \%\end{array}$ & - & $\begin{array}{c}13 \\
61.9 \% \\
56.5 \% \\
20 \% \\
\end{array}$ & \begin{tabular}{|c|}
21 \\
$100 \%$ \\
$75.9 \%$ \\
$32.3 \%$ \\
\end{tabular} \\
\hline $\begin{array}{l}\text { 32-38 Count } \\
\% \text { within age group } \\
\% \text { within gender } \\
\% \text { of Total population }\end{array}$ & 4 & 14 & - & $\begin{array}{c}18 \\
72 \% \\
42.9 \% \\
27.8 \% \\
\end{array}$ & 2 & 5 & - & $\begin{array}{c}7 \\
28 \% \\
30.4 \% \\
10.8 \% \\
\end{array}$ & \begin{tabular}{|c|}
25 \\
$100 \%$ \\
$73.3 \%$ \\
$38.5 \%$ \\
\end{tabular} \\
\hline $\begin{array}{l}39-45 \text { Count } \\
\% \text { within age group } \\
\% \text { within gender } \\
\% \text { of Total population }\end{array}$ & - & 9 & - & $\begin{array}{c}9 \\
81.8 \% \\
21.4 \% \\
13.9 \% \\
\end{array}$ & - & 1 & 1 & $\begin{array}{c}2 \\
18.2 \% \\
8.7 \% \\
3.1 \% \\
\end{array}$ & \begin{tabular}{|c|}
11 \\
$100 \%$ \\
$30.1 \%$ \\
$16.9 \%$ \\
\end{tabular} \\
\hline $\begin{array}{l}\text { Over } 45 \text { Count } \\
\% \text { within age group } \\
\% \text { within gender } \\
\% \text { of Total population }\end{array}$ & - & 5 & - & $\begin{array}{c}5 \\
83.3 \% \\
11.9 \% \\
7.7 \%\end{array}$ & - & $\begin{array}{l}1 \\
-\end{array}$ & - & $\begin{array}{c}1 \\
16.7 \% \\
4.3 \% \\
1.5 \%\end{array}$ & \begin{tabular}{|c|}
6 \\
$100 \%$ \\
$16.2 \%$ \\
$9.2 \%$
\end{tabular} \\
\hline $\begin{array}{l}\text { Total Count } \\
\% \text { within gender } \\
\% \text { of Total population }\end{array}$ & 14 & 28 & - & $\begin{array}{c}42 \\
64.6 \% \\
64.6 \% \\
\end{array}$ & 9 & 13 & 1 & $\begin{array}{c}23 \\
35.4 \% \\
35.4 \% \\
\end{array}$ & \begin{tabular}{|c|}
65 \\
$100 \%$ \\
$100 \%$ \\
\end{tabular} \\
\hline
\end{tabular}

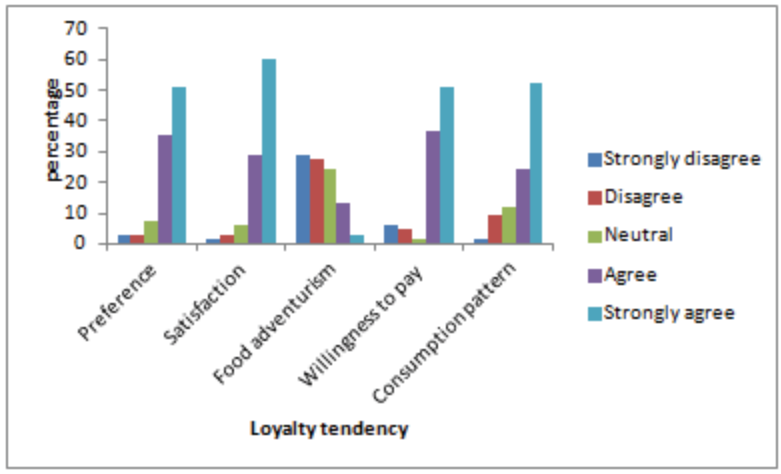

Figure 3.1: Loyalty tendency of Nigerians in South Africa to cultural food 
Table 3.4: Loyalty tendency measures

\begin{tabular}{|l|l|}
\hline \multicolumn{1}{|c|}{ Criteria } & \multicolumn{1}{c|}{ Measures } \\
\hline Preference & When it comes to food, local meals are the best options \\
\hline Satisfaction & Compared to all other meals, my local meals satisfy me the most \\
\hline Food-adventurism & I would eat any meal, as long as it is called food \\
\hline Willingness to pay & I would buy my local meals and food stuff, provided the prices are reasonable \\
\hline Consumption pattern & I eat my local meals at least twice a week \\
\hline
\end{tabular}

\section{Conclusion and Recommendation}

Culture plays a major role in peoples' preference for food. The findings of this study reveal that Nigerians in South Africa show high loyalty tendencies to their cultural food regardless of their length of stay abroad. Therefore, the Nigerian cultural food market presents many growth opportunities for the South African economy. While it is said that cultures are overlapping due to the effect of globalisation, the globalised culture is not evident in Nigerians' preference for cultural food. This paper proposes the tendency for profitable investment opportunities in the Nigerian cultural food market for potential South African business owners, especially considering the similarity between West Africans' cultural foods. Consequently, macroeconomic policy objectives could be enhanced. Moreover, the composition of the South African infrastructural facilities could enhance large scale production, which could possibly reduce production costs, thereby enabling competitive prices. Further research could investigate the monetary value consumers place on cultural food, in terms of determining specific prices consumers are willing to pay for cultural food abroad.

\section{References}

Adichie C. N. 2009. Why do South Africans hate Nigerians?

Available:http://www.guardian.co.uk/world/2009/oct/05/chimamanda-gozi-dichie-nigeria-south-africa. (Accessed April 29 2013).

Advameg, 2012. Culture of Nigeria - history, people, clothing, traditions, women, beliefs, food, customs, family.

Available: http://www.everyculture.com/MaNi/Nigeria.html\#ixzz269OcR7WU. (Accessed September 11 2012).

Beugré, C. D. and Offodile, O.F. 2001. Managing for organisational effectiveness in sub-Saharan Africa: a culture-fit model. International Journal of Human Resource Management (online), 12(4): 535-550. Available: http://www.tandfonline.com.dutlib.dut.ac.za :2048/doi/pdf/10.1080/713769650 (Accessed 10 May 2013).

Cooper, D. R. and Schindler, P.S. 2006. Business Research Methods: Statistics and probability series. 9th ed. Boston: McGraw Hill.

de Mooij, M. 2011. Consumer behaviour and culture: Consequences for global marketing and advertising. $2^{\text {nd }}$ ed. California: Sage Publications

Drusilla F. 2006. How Many Nigerians Live Outside Of Nigeria? Available:http://www.nairaland.com/19072/how-many-nigerians-liveoutside. (Accessed 12 September 2012).

Du Plessis, P. J. and Rousseau, G. G. 2007. Buyer behaviour. 3rd ed. New York: Oxford University Press.

Ember, C. R., \& Ember, M. 2001. Cross-cultural research methods. New York: Rowman \& Littlefield.

Hofstede, G. and Hofstede, G., J. 2005.Cultures and organisations: Software of the mind. $2^{\text {nd }}$ ed. New York: McGraw-Hill.

Hofstede, G., Hofstede, G., J. and Minkov, M. 2010. Cultures and organisations: Software of the mind. $3^{\text {rd }}$ ed. New York: McGraw-Hill.

Jones, M. J., 1992. Effect of food processing in Food Safety. Eagan Press. St. Paul, Minnesota, USA. 171- 201

Leedy, P. D. and Ormrod, J. E. 2005. Practical research: Planning and design. $8^{\text {th }}$ ed. New Jersey: Prentice Hall.

Neeliah, S. A and Goburdhun, D. 2007. National Food Control Systems: A Review. Food Reviews International 23, 35-51

Schiffman, L. G., Kanuk, L. L. and Wisenblit, J. 2010. Consumer behaviour. 11th ed. London: Prentice Hall.

Sekaran, U. and Bougie, R. 2013. Research methods for business: A skill-building approach. $6^{\text {th }}$ ed. Chichester: Wiley.

Shepherd R \& Raats M 2012. The psychology of food choice. Available http://www.scribd.com/doc/50357369/The-Psychology-of-FoodChoice (Accessed September 11 2013). 